\title{
Metal Demand and Deep-Sea Mining
}

\author{
F Sakellariadou* \\ University of Piraeus, Greece
}

*Corresponding author: F Sakellariadou, Oceanography \& Marine Geochemistry Lab, Department of Maritime Studies, University of Piraeus, Greece.

Received Date: December 14, 2020

Published Date: January 12, 2021

\begin{abstract}
The 21st century faces a high need for resources and specifically critical metals. As terrestrial mineral deposits are depleted, the exploration of marine resources seems to be a promising solution. Significant metal abundances are found in the deep seabed and particularly in polymetallic nodules, cobalt-rich ferromanganese crusts and seafloor massive sulphides. However, deep-sea mining causes many environmental impacts and deep-sea ecosystems are less understood as well as difficult to monitor. The adoption of a circular economy and the rejection of the throwaway attitude will help managing finite resources while meeting the needs of a growing world population with lower risks to humankind and the environment.
\end{abstract}

\section{Opinion}

The world's population, today numbering more than 7.8 billion people, is projected to increase to 8.5 billion in 2030 and peak at 11.2 billion by 2100 . The world economy is expected to grow at an annual average rate of around $2.6 \%$ between 2016 and 2050. The growing population, the increase in GDP levels and the consumption patterns of modern society lead to a higher need for resources. The global ocean covers approximately the $71 \%$ of our planet's surface. It has an enormous importance due its economic values and the wide range of ecosystem services. Nowadays, it is well acknowledged that the Ocean and its resources are vital for tackling the several challenges that the Earth faces in the decades ahead. The depletion of terrestrial mineral deposits and the continuous rise of the demand for critical metals, arouse the interest for the exploration of marine mineral resources. Seabed mining is an emerging industry of the blue economy. Advances in deep-sea technology make seabed mining commercially viable. Critical metals [1] are crucial for emerging green and artificial intelligence technologies and achieving the targets of sustainable development. Metals, like manganese, iron, cobalt, copper, nickel, zinc, lithium, titanium, tellurium and the rare earth elements (REE), are hosted in various seabed resources [2]. Metal mineral resources are deep-sea polymetallic nodules, cobalt-rich ferromanganese crusts, seafloor massive sulphides, marine phosphorites, REY -rich muds, as well as placer deposits [3-9]. Significant abundances of nodules occur in four abyssal areas, the Clarion-Clipperton Zone in the Pacific Ocean, the Peru Basin in the Eastern Pacific Ocean, the Penrhyn basin very near the Cook Islands in the South Pacific Ocean, and the central Indian Ocean, at water depth ranging from 3,500 to $6,500 \mathrm{~m}$. Polymetallic nodules consist mainly of manganese, iron, copper, nickel and cobalt along with other interest elements like zinc, lithium, molybdenum, titanium and rare earth elements plus yttrium (REY). Up to $19 \%$ of the known polymetallic nodules are in Exclusive Economic Zones [10]. Cobalt rich ferromanganese crusts with a high mining potential are found mainly in water depths from 800 to 2,500 m, especially in the Central Pacific Ocean called the "Prime Fe-Mn Crust Zone (PCZ). Additional exploration areas are the NE Atlantic margin and the Indian Ocean [2,11,12]. Ferromanganese crusts have a high enrichment in cobalt, tellurium, nickel, molybdenum and REY. Up to 54\% of the known crust are in Economic Exclusive Zones [10]. Seafloor massive sulphides (SMS) are formed on hydrothermal sites, along mid-ocean ridges, and especially on the East Pacific Rise, the Southern East Pacific Rise, the North Pacific Rise and the Mid-Atlantic Ridge. Seafloor massive sulphides are found at depths varying from 1,500 to $3,500 \mathrm{~m}$. Areas 
with a particular interest for SMS mining are the deposits in the Exclusive Economic Zones (EEZ) of Papua New Guinea (in the South Western Pacific Ocean) and New Zealand [13]. Up to $42 \%$ of the known polymetallic sulphides are in Exclusive Economic Zones [10]. Marine phosphorites are found in lagoons, insular areas, continental margins and seamounts [14]. They are mainly explored for phosphorus and manganese with co- products and by-products REY, cobalt, nickel, tellurium, and niobium. The marine zones with a high potential for marine phosphorites exploration are the Clatham Rise off New Zealand, the area offshore the state of Baja California and the area on the shelf off Namibia. REY-rich deep-sea muds are found in the eastern-South Pacific and the North Pacific Ocean [3] as well as in the western North Pacific Ocean near Minamitorishima Island [15]. Placer deposits of heavy and weathering resistant minerals are found in various locations on continental shelves. In some cases, their location mark ancient coastline. Coastal minerals are ilmenite, sillimanite, garnet, zircon, monazite, rutile, titanite, allanite, uraninite, xenotime and apatite. Monazite and sometimes xenotime are the REE-bearing minerals in placer deposits $[16,17]$. Both of them are radioactive as they contain thorium and, less commonly, uranium.

Comparing seabed mining with land-based mineral extraction, we find out that each seabed site with high mining potential shows a metal enrichment in more than one metal. This is an important advantage. Additionally, as marine mineral deposits are mainly exposed on the seabed, the mining process produces smaller quantities of waste rocks. Mining of the deep seabed does not require permanent mining structure [18]. It takes place via dredging or cutting processes and transport of the material to a support vessel at sea surface. After a minimal handling of the mineral-bearing material onboard, it is transferred to a second and smaller vessel that transports it to shore. Wastewaters and sediment material are returned to the ocean. Deep-sea mining activities, as any kind of human development, cause significant negative impacts to the marine environment and the bio-communities. The deepsea floor (below $200 \mathrm{~m}$ ) covers more than $87 \%$ of the ocean floor and it is regarded as one of the least well-understood ecosystems. Deep-sea is inhabited by as estimated 10 million species that have slow dynamics, high sensitivity to anthropogenic disturbances and significant environmental stability [19]. Moreover, benthic organisms contain the largest number of undiscovered species. Deep-sea is regarded as an exceptionally vulnerable area with a very high ecological value. We now know that the conservation of deep-sea biodiversity is crucial for the sustainable functioning of the global ocean. In general, the environmental impacts of deepsea mining could be detected at the seabed, the seawater column as well as the atmosphere. Among them, the most important are habitat alteration, sediment disturbance, plume discharges, toxic compounds release, light and noise generation and air emissions. In agreement with the United Nations Convention on the Law of the Sea (UNCLOS), the International Seabed Authority (ISA) regulates deep-sea exploration and mining of the international seabed area (defined as "the seabed and ocean floor and the subsoil thereof, beyond the limits of national jurisdiction" [20]). ISA has entered thirty 15-years contracts for the exploration of three commodities (polymetallic nodules, polymetallic sulphides and cobalt-rich ferromanganese crusts) in the international seabed area, and more particularly in the Clarion-Clipperton Zone, the Indian Ocean, the Mid Atlantic Ridge, the South Atlantic Ocean and the Pacific Ocean. ISA has full responsibility for taking all necessary measures as well as adopting regulations and procedures for the protection and preservation of the marine ecosystem and the elimination of environmental impacts of deep-sea mining.

It should be also noticed that seabed mining might cause problems to existing maritime industries. Therefore, externalities and conflicts with them should be eliminated. The more sustainable use of marine resources and the better management of existing and new maritime activities could be successfully achieved by following the marine spatial planning (MSP) approach. Concluding, the increasing demand for critical metals is an indication of our modern society geared to throw-away consumption. The 21st century will face a crisis in resources. Our challenge is to meet the needs of the global population with the minimum environmental harm. The only way to fulfill this target is to change our lifestyles and apply a circular economy. Taking a critical look at our values and actions and willing to change our behavior we move towards new ideas and approaches such as recycling, repair, reuse, recovery and eco-design. In this manner, the demand for more resources and the pressure put on the environment will be substantially reduced. In any case, the use of the untapped potential of the ocean will require responsible and sustainable approaches.

\section{Acknowledgment}

None.

\section{Conflicts of Interest}

No conflict of interest.

\section{References}

1. Graedel TE, Harper EM, Nassar NT, Nuss P, Reck BK (2015) Criticallity of metals and metalloids. Proc. Natl Acad Sci USA 112: 4257-4262.

2. Hein JR, Mizell K, Koschinsky A, Conrad TA (2013) Deep-ocean mineral deposits as a source of critical metals for high- and green-technology applications: Comparison with land-based resources. Ore Geol. Reviews 51: $1-14$.

3. Kato Y, Fujinaga K, Nakamura K, Takaya Y, Kitamura K (2011) Deep-sea mud in the Pacific Ocean as a potential resource for rare-earth elements. Nature Geoscience 4: 535-539.

4. Hein JR, Conrad TA, Staudigel H (2015) Seamount mineral deposits. A source of rare metals for high-technology industries. Oceanography 23 : 184-189

5. Hein JR, Koschinsky A, Bau M, Manheim FT, Kang J-K (2000) Cobalt-rich ferromanganese crusts in the Pacific. In: Cronan DS (Ed.) Handbook of marine mineral deposits, CRC Press, Boca Raton, Florida, pp. 239-279.

6. Rona PA (2008) The changing vision of marine minerals. Ore Geology Reviews 33: 618-666. 
7. Lusty PAJ, Hein JR, Josso P (2018) Formation and occurrence of ferromanganese crusts: Earth's storehouse for critical metals. Elements 14: 313-318.

8. Hein JR, Koschinsky A (2014) Deep-ocean ferromanganese crusts and nodules. Treatise Geochemistry 13: 273-291.

9. Marino E, González FJ, Lunar R, Reyes J, Medialdea T (2018) Highresolution analysis of critical minerals and elements in Fe-Mn crusts from the Canary Island Seamount Province (Atlantic Ocean). Minerals 8 (7): 285.

10. Levin LA, Amon DJ, Lily H (2020) Challenges to the sustainability of deep-seabed mining. Nat Sustain 3: 784-794.

11. Marino E, González FJ, Somoza L, Lunar R, Ortega L (2017) Strategic and rare elements in Cretaceous-Cenozoic cobalt-rich ferromanganese crusts from seamounts in the Canary Island Seamount Province (northeastern tropical Atlantic). Ore Geology Reviews 87: 41-61.

12. Usui A and Someya M (1997) Distribution and composition of marine hydrogenetic and hydrothermal manganese deposits in the northwest Pacific. In: Nicholson K, Hein JR, Bühn B, Dasgupta S (Eds.), Manganese Mineralization: Geochemistry and Mineralogy of Terrestrial and Marine Deposits, Geological Society of London Special Publication No. 119, London pp. 177-198.
13. Boschen EE, Rowden AA, Clark MR, Gardner JPA (2013) Mining of deep-sea seafloor massive sulfides: A review of the deposits, their benthic communities, impacts from mining, regulatory frameworks and management strategies. Ocean and Coastal Management 84: 54-67.

14. McArthur JM, Walsh JN (1984) Rare-earth geochemistry of phosphorites. Chemical Geology 47: 191.

15. Takaya Y, Yasukawa K, Kawasaki T, Fujinaga K, Ohta J, et al. (2018) The tremendous potential of deep-sea mud as a source of rare-earth elements. Scientific Report 8 (5763).

16. Sengupta D and Van Gosen BS (2016) Rare earth and critical elements in ore deposits. Reviews in Economic Geology 18: 81-100.

17. Jaireth S, Hoatson DM, Miezitis Y (2014) Geological setting and resources of the major rare-earth-element deposits in Australia. Ore Geology Reviews 62: 72-128.

18. Lodge MW and Verlaan PA (2018) Deep-sea mining: international regulatory challenges and responses. Elements 14: 331-336.

19. Jones DOB, Durden JM, Murphy K, Gjerde KM, Gebicka A, et al. (2019) Existing environmental management approaches relevant to deep-sea mining. Marine Policy 103: 172-181.

20. International Seabed Authority (ISA) (2020). 